\title{
Kajian Literatur: Hubungan Tingkat Pengetahuan Kesehatan dan Keselamatan Kerja (K3) dengan Kejadian Kecelakaan Kerja
}

\author{
Delly Safira Hedaputri ${ }^{1}$, Rubayat Indradi ${ }^{2}$, Anung Putri Illahika ${ }^{3}$ \\ ${ }^{1,2,3}$ Fakultas Kedokteran, Universitas Muhammadiyah Malang
}

\begin{abstract}
ABSTRAK
Tren kecelakaan kerja kian meningkat dan mengakibatkan berbagai dampak mulai dari kerugian dapat dihitung atau direct cost hingga kerugian tidak dapat dihitung atau indirect cost menjadikannya topik yang tak pernah berhenti dibahas. Kejadian kecelakaan kerja yang tinggi ini dapat disebabkan oleh tiga faktor yakni manusia, pekerjaan, dan lingkungan tempat kerja. Tingkat pengetahuan Kesehatan dan Keselamatan Kerja (K3) yang termasuk dalam faktor manusia merupakan pokok penting dalam menciptakan lingkungan kerja yang sehat, aman, tidak tercemar, dan bebas kecelakaan kerja sehingga meningkatkan produktivitas dan efisiensi para pekerja serta dapat menurunkan kejadian kecelakaan kerja. Tujuan karya tulis ini untuk mengetahui hubungan tingkat pengetahuan K3 terhadap kejadian kecelakaan kerja. Karya tulis ini merupakan studi literatur secara kuantitatif. Pustaka berupa artikel dan buku literatur diperoleh melalui beberapa mesin pencari, diantaranya 2 dari Google, 10 dari Google Books, 17 dari Google Scholar, 4 dari PubMed, 6 dari NCBI, 4 dari Science Direct, dan 1 dari BMC. Kriteria jurnal nasional terakreditasi Sinta (S3-S5) dan jurnal internasional terakreditasi Scopus (Q2) maupun non-Scopus dengan tahun terbit paling lama adalah 2015. Hasil pengkajian menunjukkan bahwa tingkat pengetahuan K3 berhubungan terhadap kejadian kecelakaan kerja dimana semakin tinggi tingkat pengetahuan K3 pada pekerja di suatu tempat kerja maka akan semakin rendah kejadian kecelakaan kerjanya. Kesimpulan yang didapatkan adalah terdapat hubungan antara tingkat pengetahuan K3 terhadap kejadian kecelakaan kerja. Saran: perlu dilakukan penelitian terkait hal-hal yang mempengaruhi tingkat pengetahuan K3 dan variabel-variabel lain yang mempengaruhi kejadian kecelakaan kerja beserta hubungan keduanya di sektor tertentu.
\end{abstract}

Kata kunci: tingkat pengetahuan; Kesehatan dan Keselamatan Kerja (K3); kecelakaan kerja

\begin{abstract}
Introduction: The trend of work accidents increased and gave various impacts ranging from countable losses or direct costs to uncountable losses or indirect costs, makes it a topic that never stops being discussed. This high incidence of work accidents can be caused by three factors, there are: human, work, and the work environment. The level of Occupational Health and Safety (OHS) knowledge, which is included in the human factor is an important point in building a healthy, safe, not polluted work environment, and free of work accidents in order to increase the productivity and efficiency of workers and able to reduce the incidence of work accidents. Objective: This paper aims to know the correlation between the level of OHS knowledge and work accidents. Method: This paper is a quantitative study of kinds of literature. Bibliography like articles and literature books were obtained through several search engines, there are 2 from Google, 10 from Google Books, 17 from Google Scholar, 4 from PubMed, 6 from NCBI, 4 from Science Direct, and 1 from BMC. Criteria for national journals accredited by Sinta (S3-S5) and international journals accredited by Scopus (Q2) and non-Scopus with the longest the publication year of 2015. Results and Discussion: The result of this assessment shows that level of OHS knowledge associated with the incidence of work accidents in which the higher level of OHS knowledge on workers in a workplace would be the lower incidence of work accidents. Conclusion: There is a relationship between the level of OHS knowledge and work accidents. Further research is needed about matters that affect the level of OHS knowledge and other variables that affect work accidents and the relationships in particular sectors.
\end{abstract}

Keywords: knowledge level; Occupational Health and Safety (OHS); work accidents

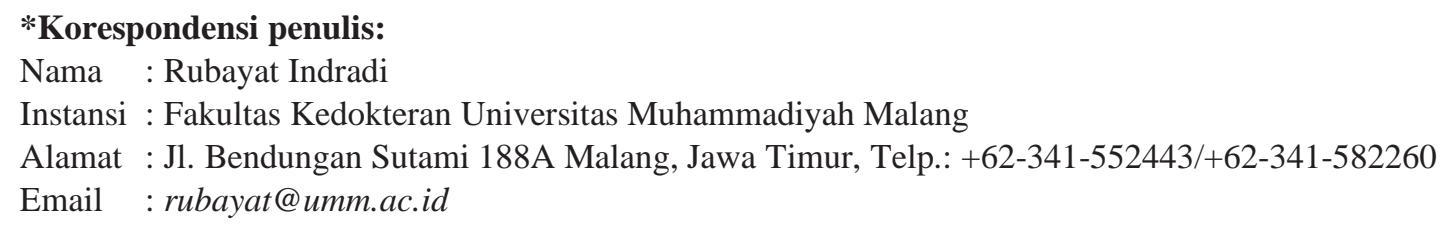




\section{Pendahuluan}

Kecelakaan kerja merupakan suatu kejadian yang berasal dari perjalanan atau dalam pekerjaan yang menyebabkan cedera fatal atau non-fatal. ${ }^{1}$ Hingga saat ini angka kecelakaan kerja kian meningkat sehingga menjadi topik yang tak pernah berhenti dibahas. Berdasarkan data International Labour Organization (ILO) pada tahun 2017 setiap harinya didapatkan 6.400 pekerja meninggal dan 860.000 pekerja mengalami penyakit akibat kerja dan kecelakaan kerja di seluruh dunia. Data BPJS Ketenagakerjaan juga mengungkapkan angka kecelakaan kerja yang tercatat di Indonesia tahun 2017 sebanyak 123.041 kasus dan tahun 2018 mencapai 173.105 kasus sedangkan Dinas Tenaga Kerja dan Transmigrasi Provinsi Jawa Timur pada tahun 2017 mendapati 14.552 kasus kecelakaan kerja di Jawa Timur yang mengakibatkan 101 pekerja meninggal, 768 pekerja mengalami kecacatan, 3.329 dalam pengobatan, dan 10.354 sembuh. ${ }^{2,3}$

ILO mengemukakan angka kejadian kecelakaan kerja yang tinggi disebabkan oleh manusia, pekerjaan, dan lingkungan tempat kerja. ${ }^{1}$ Salah satu yang termasuk dalam faktor manusia ialah tingkat pengetahuan Kesehatan dan Keselamatan Kerja (K3) karena menurut (Irzal, 2016) dengan menciptakan lingkungan kerja sehat, aman, tidak tercemar dan bebas kecelakaan kerja akan meningkatkan produktivitas dan efisiensi para pekerja. ${ }^{4}$ Dampak dari kecelakaan kerja ini berupa direct cost yakni kerugian yang dapat dihitung langsung seperti biaya pertolongan pertama kecelakaan dan indirect cost yakni kerugian yang tidak terlihat seperti hilangnya waktu dan tenaga kerja yang mengalami kecelakaan. ${ }^{5}$

Penelitian terkait yang dilakukan oleh Suxia Liu et al. pada tahun 2020 menyatakan bahwa pengetahuan keselamatan secara signifikan menengahi hubungan antara Occupational Health and Safety Management Frameworks (OHSMF) dan kecelakaan serta cedera di tempat kerja. ${ }^{6}$ Penelitian terkait juga dilakukan oleh M. Dita et al. pada tahun 2019 menyatakan bahwa terdapat hubungan korelasi antara pengetahuan tentang kecelakaan kerja dengan perilaku kerja yang aman dimana pengetahuan yang baik dapat meminimalkan tindakan tidak aman para pekerja. ${ }^{7}$ Berdasarkan uraian di atas didapatkan bahwa penulisan artikel ini bertujuan untuk mengetahui kajian literatur tentang hubungan tingkat pengetahuan K3 dengan kejadian kecelakaan kerja.

\section{Metode}

Karya tulis ini merupakan studi literatur secara kuantitatif. Pustaka berupa artikel dan buku literatur diperoleh melalui beberapa mesin pencari, diantaranya 2 dari Google, 10 dari Google Books, 17 dari Google Scholar, 4 dari PubMed, 6 dari NCBI, 4 dari Science Direct, dan 1 dari $B M C$. Kriteria jurnal nasional terakreditasi Sinta dan jurnal internasional terakreditasi Scopus maupun non-Scopus dengan tahun terbit paling lama adalah 2015. Karya tulis ini dilakukan dengan mengidentifikasi hasil dari penelitian-penelitian sebelumnya yang berkaitan dengan judul yakni hubungan antara tingkat pengetahuan K3 pekerja terhadap kejadian kecelakaan kerja.

\section{Hasil dan Pembahasan}

Secara umum, masalah keselamatan dan kesehatan kerja (K3) di Indonesia masih sering terabaikan. Hal ini ditunjukkan dengan masih tingginya angka kecelakaan kerja yang sangat memprihatinkan. Tingkat kepedulian di dunia usaha terhadap K3 juga tergolong rendah padahal pekerja adalah aset berharga pada setiap perusahaan. ${ }^{8} \mathrm{~K} 3$ berkaitan dengan semua aspek kesehatan dan keselamatan di tempat kerja dengan fokus utamanya adalah sebagai bentuk pencegahan bahaya di tempat kerja. ${ }^{6}$

Keselamatan di tempat kerja diibaratkan sebagai sebuah investasi bisnis karena jika keselamatan kerja mengurangi kerugian finansial maka akan ada efek positif pada aspek kondisi kerja yakni terjadi penurunan kecelakaan kerja, tingkat produktivitas meningkat, dan kualitas hidup pekerja meningkat. ${ }^{9}$ Pentingnya peran K3 
salah satunya ditunjukkan pada sektor pertanian yang dijelaskan pada penelitian Kolstrup \& Ssali (2016) dimana pertanian merupakan penggerak utama perekonomian Uganda sehingga peningkatan pengetahuan K3 akan menambah nilai bagi negara melalui kondisi kerja yang lebih baik, produktivitas pekerja yang lebih tinggi, dan populasi pertanian yang lebih sehat. ${ }^{10} \mathrm{~K} 3$ juga berperan dalam komitmen pekerja dimana jika perusahaan memiliki manajemen $\mathrm{K} 3$ yang memadai maka pekerjanya akan memiliki komitmen yang kuat terhadap perusahaannya karena mereka menganggap bahwa kesehatan dan keselamatan mereka telah terjamin. ${ }^{11}$

Konsep terkait K3 ini dapat didukung dengan adanya Sistem Manajemen Keselamatan dan Kesehatan Kerja (SMK3) karena pembentukan dan penerapannya menjadi langkah awal dalam manajemen terstruktur sistem kesehatan dan keselamatan di lingkungan kerja. ${ }^{12}$ Tujuan utama penerapan SMK3 adalah menciptakan manajemen K3 di tempat kerja dengan mengintegrasikan pihak manajemen, pekerja, kondisi, dan lingkungan kerja untuk mencegah dan mengurangi kecelakaan dan penyakit akibat kerja, serta menciptakan tempat kerja yang aman, efisien dan produktif. Penerapan SMK3 ini melibatkan fungsi manajemen diantaranya program K3, pengorganisasian, pelaksanaan program, dan pengendalian. ${ }^{13}$

Robert Trevethan pada penelitiannya tahun 2017 yang berjudul "Deconstructing and Assessing Knowledge and Awareness in Public Health Research" menyatakan bahwa pengetahuan adalah mengetahui keberadaan sesuatu atau pemahaman tentang situasi atau subjek pada saat ini berdasarkan informasi atau pengalaman yang telah didapatkan. ${ }^{14}$ Pengukuran pengetahuan dapat dilakukan dengan wawancara atau angket berupa kuesioner yang menanyakan tentang isi materi yang ingin diukur dari responden. Pengetahuan dinilai baik apabila mampu mengungkapkan informasi dari suatu objek dengan benar. Bila hanya mampu mengungkapkan sedikit informasi maka dikategorikan memiliki pengetahuan kurang baik. ${ }^{15}$ Pengetahuan K3 berarti segala sesuatu yang diketahui terkait K3. Pengetahuan tersebut dipengaruhi oleh intelegensi yang berasal dari pengolahan informasi, perbedaan informasi yang diperoleh terkait $\mathrm{K} 3, \mathrm{P} 2 \mathrm{~K} 3$ belum berjalan maksimal, pelatihan $\mathrm{K} 3$, dan penyuluhan $\mathrm{K} 3$. Pengetahuan K3 ini dapat diasah melalui beragam cara. Salah satunya dijelaskan pada penelitian Syaputra (2017) yang berjudul "Hubungan Pengetahuan dan Motivasi K3 dengan Kecelakaan Kerja Karyawan Produksi PT. Borneo Melintang Buana Eksport" yakni melalui safety talk kepada semua pekerja sebelum memulai pekerjaan, menjelaskan Standar Operasional Prosedur (SOP) secara berulang, dan rutin memberikan pelatihan bagi pekerja. Safety talk termasuk dalam komunikasi K3 antara manusia dengan manusia secara langsung dan termasuk dalam komunikasi beberapa kelompok yang dilakukan melalui kontak individu sehingga dapat membentuk perilaku seseorang. ${ }^{16}$ Seperti pada penelitian "Hubungan Kepatuhan dan Pengetahuan Tentang APD dengan Safety Talk di Unit Maintenance Perusahaan Semen" yang dilakukan Gumelar dan Ardyanto (2018) terhadap 67 responden melalui uji statistik menggunakan pearson dan chi square menunjukan hasil terdapat hubungan antara safety talk dan pengetahuan tentang APD dengan $p$ value 0,000 dimana pekerja yang mengikuti safety talk secara efektif memiliki kepatuhan penggunaan APD yang positif dan memiliki tingkat pengetahuan tentang APD yang baik. Maka, safety talk dapat mengasah pengetahuan dan membentuk perilaku patuh menggunakan APD pada pekerja di perusahaan semen tersebut. ${ }^{17}$

Selain safety talk, upaya lain untuk meningkatkan pengetahuan K3 yaitu melalui pendidikan dan pelatihan K3. Menurut Rumchev et al. (2019) pada "Agricultural Dust Exposures and Health and Safety Practices Among Western Australia Wheatbelt Farmers During Harvest" terhadap 29 respoden petani, pendidikan dan pelatihan dapat meningkatkan kemampuan 
identifikasi bahaya, mendorong adopsi proses, dan perilaku kerja yang tidak hanya akan menghindari dari paparan berbahaya tetapi juga mampu mengidentifikasi elemen dan situasi berbahaya lainnya, serta sebagai upaya perbaikan untuk mengurangi hasil yang merugikan. Dalam penelitian ini juga dijabarkan bahwa mayoritas pemilik tambak (36\%) kembali menggunakan smartphone dan situs web seluler mereka untuk mendapatkan informasi terkait K3 karena dirasa dapat memberikan manfaat yang jauh lebih signifikan. ${ }^{18}$ Ternyata, hal ini telah dibuktikan pada penelitian "Evaluation of Safety Management and Leadership Training Using Mobile Technologies Among Logging Supervisors" terhadap 31 responden pekerja lakilaki pengawas penebangan di sektor perhutanan dimana pelatihan $\mathrm{K} 3$ berbasis digital dianggap menyenangkan, mudah digunakan, efektif, dan lebih komprehensif. ${ }^{19}$ Jadi, pengetahuan K3 dapat ditingkatkan dengan melakukan upaya promotif safety talk, pendidikan $\mathrm{K} 3$, dan pelatihan $\mathrm{K} 3$ kepada para pekerja di tempat kerja yang berbasis digital agar lebih efektif.

Pengetahuan memegang peran penting dalam setiap perilaku seseorang. ${ }^{15}$ Dibuktikan dalam penelitian Susanto (2019) berjudul "Implementasi Perbaikan Perilaku Kerja Aman Menggunakan Pendekatan Behaviour-Based Safety pada Industri Batik di Kota Semarang" terhadap 25 responden menggunakan metode DO IT (Define, Observe, Intervene, and Test) pada regresi linier berganda yang menghasilkan bahwa perilaku kerja aman dipengaruhi oleh pengetahuan, komunikasi dan alat pelindung diri dengan masing-masing nilai $\mathrm{t}-2,396 ; 3,408$; dan 9,955. ${ }^{20}$ Terkait hal ini, Rinawati et al. (2016) juga menjelaskan dalam "Pengaruh Tingkat Pengetahuan Terhadap Pelaksanaan Pemakaian Alat Pelindung Diri Sebagai Upaya Pencapaian Zero Accident di PT. X" terhadap 55 responden dalam uji chi square dengan nilai $p$ value 0,009 berarti responden yang memiliki pengetahuan tinggi akan disiplin menggunakan APD. ${ }^{15}$ Didukung pula pada penelitian Oztas et al. (2018) yang berjudul "Knowledge Level, Attitude, and
Behaviors of Farmers in Cukurova Region Regarding The Use of Pesticides" pada 420 petani musiman di Distrik Karatas, Provinsi Adana, Turki, menggunakan kuesioner dengan metode interview, didapatkan hasil bahwa pengetahuan yang tidak memadai tentang penggunaan pestisida yang aman dan penggunaan alat pelindung diri dapat mengurangi perilaku kerja aman petani dari potensi risiko pestisida. ${ }^{21}$ Penelitian terkait juga dilakukan oleh Ismail et al. (2018) dalam "Occupational Exposure to HIV in A Developing Country: Assessing Knowledge and Attitude of Healthcare Professional Before and After an Awareness Symposium" terhadap 364 responden dan didapatkan hasil bahwa seiring dengan meningkatnya pengetahuan maka akan terjadi perubahan sikap yang positif terkait keamanan terhadap HIV. ${ }^{22}$ Artinya, pengetahuan mempengaruhi perilaku pekerja dimana semakin rendah tingkat pengetahuan pekerja terutama terkait K3 maka akan semakin rendah perilaku kerja aman dari para pekerja.

Hubungan antara pengetahuan K3 dengan perilaku pekerja ini telah dibuktikan pada penelitian Teja et al. (2017) yang berjudul "Pengaruh Pengetahuan Keselamatan dan Kesehatan Kerja Terhadap Perilaku Pekerja Konstruksi pada Proyek Jalan Tol Nusa DuaNgurah Rai-Benoa" kepada 137 responden didapatkan nilai koefisien korelasi 0,262 dan berdasarkan interpretasi koefisien nilai korelasi berada diantara $0,200-0,399$ sehingga terdapat tingkat korelasi yang rendah antara pengetahuan K3 dengan perilaku pekerja. ${ }^{23}$ Sedangkan arah korelasinya telah dinyatakan oleh penelitian Novianto et al. (2016) dalam "Analisis Pengaruh Kesehatan dan Keselamatan Kerja (K3) Terhadap Kinerja Pekerja Konstruksi pada Proyek Pembangunan Fly Over Palur" dengan analisis regresi linear berganda meluputi uji validitas dan realibilitas, uji asumsi klasik (multikolinieritas, normalitas autokorelasi, dan heterokedasitas), dan uji regresi (uji $f$ dan uji t) didapatkan secara simultan variabel bebas dalam Keselamatan dan Kesehatan Kerja yang terdiri dari Kesehatan 
Kerja dan Keselamatan Kerja (X1 dan X2) mempunyai pengaruh signifikan terhadap variabel terikat yaitu Kinerja Pekerja Konstruksi (Y). Ditandai dengan persamaan $\mathrm{Y}=14,706+$ $1,309 \mathrm{X} 1+1,098 \mathrm{X} 2$. Hal ini menunjukkan bahwa hubungan pengetahuan K3 dengan perilaku pekerja memiliki pengaruh searah yang artinya jika pengetahuan K3 meningkat maka kinerja pekerja juga akan meningkat. ${ }^{24}$

Kecelakaan kerja lebih sering terjadi di sektor-sektor seperti pertambangan, industri, konstruksi, dan pertanian. Namun, 50\% dari kecelakaan kerja dapat dicegah dengan mudah, 48\% dapat dicegah dengan upaya sistematis, dan hanya $2 \%$ kecelakaan kerja yang tidak dapat dicegah sehingga diperlukan proses analisis kecelakaan kerja berdasarkan jenis dan penyebabnya untuk menghasilkan solusi pencegahan. ${ }^{25}$ Angka kecelakaan kerja dapat ditekan dengan memberikan edukasi terkait K3 dan penerapan sikap terhadap keselamatan kerja pada pekerja. ${ }^{26}$

Edukasi terkait $\mathrm{K} 3$ telah dijelaskan oleh penelitian Aluko et al. (2016) yakni melalui promosi praktik keselamatan dan meminimalkan paparan bahaya seperti menyediakan peralatan keselamatan, rutin melaksanakan pelatihan pekerja terkait keselamatan, penguatan kapasitas, dan kemampuan pekerja yang memadai melalui pelatihan di segala fasilitas yang perlu diadakan secara wajib. ${ }^{27}$ Setelah diterapkan dengan baik, pekerja perlu untuk mematuhi segala peraturan dan prosedur keselamatan sehingga dapat meminimalisir terjadinya kecelakaan kerja. $^{28}$ Kepatuhan ini dapat ditingkatkan melalui pemantauan penegakan hukum terkait keselamatan kerja di tempat kerja. ${ }^{27}$

Selain itu, upaya penting untuk melindungi pekerja dari potensi bahaya yang ada yaitu melalui melakukan identifikasi bahaya, penilaian, dan pengendalian risiko serta melakukan risk mapping yakni pemetaan bahaya di tempat kerja yang memiliki potensi risiko bahaya tinggi dan dapat mengakibatkan terjadinya kecelakaan kerja maupun penyakit akibat kerja di masa yang akan datang. ${ }^{29}$ Yanar $e t$ al. (2019) dalam penelitiannya "The Interplay Between Supervisor Safety Support and Occupational Health and Safety Vulnerability on Work Injury" terhadap 2.390 responden yang dipekerjakan lebih dari 15 jam per minggu di tempat kerja dengan bentuk analisis berupa interaksi aditif model log-binominal regresi, juga memiliki cara untuk melindungi pekerja yakni dengan membangun kapasitas pengetahuan supervisor terkait risiko di tempat kerja khususnya di perusahaan yang susah untuk mengurangi bahaya kerja atau susah untuk melakukan perubahan besar misalnya pada perusahaan kecil dimana memiliki keterbatasan biaya untuk melakukan pelatihan pada pekerjanya. ${ }^{30}$

Hubungan tingkat pengetahuan K3 terhadap kejadian kecelakaan kerja telah dibuktikan oleh beberapa penelitian. Pertama, penelitian kuantitatif "Komitmen Manajemen, Pengetahuan, Perilaku dalam K3 dan Kecelakaan Kerja Perawat di Rumah Sakit Swasta di Yogyakarta" dilakukan oleh Pratiwi et al., (2016) pada sebuah rumah sakit swasta di Yogyakarta dengan metode cross sectional terhadap 73 perawat sebagai responden yang diambil secara simple random sampling, diperoleh hasil bahwa terdapat hubungan negatif antara pengetahuan K3 dan kecelakaan kerja perawat di unit berisiko. Artinya semakin baik pengetahuan perawat maka semakin rendah kejadian kecelakaan kerja. Hal ini ditunjukkan dengan hasil analisis regresi yakni nilai koefisian regresi $-0,403$ dan $p$ value $0,000 .^{29}$

Selanjutnya pada tahun tersebut juga terdapat penelitian sejalan berupa survei analitik cross sectional berjudul "Hubungan Antara Pengetahuan dan Sikap Tentang K3 dengan Kejadian Kecelakaan Kerja pada Kelompok Nelayan di Desa Belang Kecamatan Belang Kabupaten Minahasa Tenggara" dilakukan oleh Kalalo et al., (2016) terhadap 50 nelayan sebagai responden yang diambil secara total sampling dengan hasil uji fisher's exact. Diperoleh nilai $p$ value 0,000 dan nilai POR $(95 \%$ CI) sebesar 1,700 yang artinya responden dengan tingkat 
pengetahuan K3 kurang akan lebih berisiko mengalami kecelakaan kerja dibandingkan dengan responden dengan tingkat pengetahuan K3 baik. Maka, secara statistik menyatakan bahwa terdapat hubungan antara pengetahuan tentang K3 dengan kejadian kecelakaan kerja. ${ }^{31}$ Ketiga, penelitian kuantitatif cross sectional Syaputra (2017) yaitu "Hubungan Pengetahuan dan Motivasi K3 dengan Kecelakaan Kerja Karyawan Produksi PT. Borneo Melintang Buana Eksport" terhadap 67 responden bagian produksi yang diambil secara purposive sample di perusahaan yang bergerak di bidang jasa perdagangan dan industri pabrik furniture serta accessories didapatkan hasil uji chi square yakni terdapat hubungan signifikan antara pengetahuan dengan kejadian kecelakaan kerja dengan $p$ value 0,000 dan RP 2,75 dan nilai CI 1,54-4,90. Nilai RP 2,75 menunjukkan bahwa pekerja yang mempunyai pengetahuan baik berpeluang 2,75 kali untuk tidak mengalami kecelakaan kerja dibandingkan dengan pekerja yang mempunyai pengetahuan tidak baik. Sedangkan hasil analisis univariat pada penelitian ini didapatkan 38 responden $(56,72 \%)$ memiliki pengetahuan yang baik dan 36 responden $(53,73 \%)$ mengalami kecelakaan kerja rendah. ${ }^{16}$

Keempat, Rudyarti (2017) melakukan penelitian deskriptif analitik cross sectional berjudul "Hubungan Pengetahuan Keselamatan dan Kesehatan Kerja dan Sikap Penggunaan Alat Pelindung Diri dengan Kejadian Kecelakaan Kerja pada Pengrajin Pisau Batik di PT.X" terhadap 31 responden bagian produksi yang diambil secara total sampling. Didapatkan hasil analisis bivariat RX1 -0,400 dan p value 0,026 yang artinya terdapat hubungan signifikan antara pengetahuan K3 dengan kejadian kecelakaan kerja dimana penurunan pengetahuan $\mathrm{K} 3$ secara nyata akan meningkatkan kejadian kecelakaan kerja di tempat kerja. Kuat hubungan diantara keduanya ditunjukkan pada hasil analisis multivariat menggunakan uji regresi dengan besar koefisien regresinya $-0,412 .{ }^{26}$ Kelima, M. Dita et al., (2019) dalam ICO-HELICS International Conference on Health, Technology and Life Sciences memaparkan hasil studi analitik observasional cross sectional-nya yang berjudul "The Correlation Between Knowledge About Occupational Accidents and Safe Work Behaviors Among Employees at the Production Division of PT. X Indonesia" bahwa terdapat hubungan korelasi antara pengetahuan tentang kecelakaan kerja dengan perilaku kerja yang aman dimana pengetahuan yang baik dapat meminimalkan tindakan tidak aman para pekerja. Dibuktikan pada hasil uji Spearman terhadap 46 responden dengan nilai koefisien korelasi 0.824 dan $p$ value $0.000 .^{7}$

Keenam, hasil yang sama didapatkan oleh survei cross sectional Suxia Liu et al., (2020) pada penelitiannya di 3 perusahaan minyak dan gas pemerintah Ghana (Ghana National Petroleum Company (GNPC), Ghana National Gas Company (GNGC), dan The Tema Oil Refinery (TOR)) terhadap 699 responden yang diambil secara purposive sampling. Hasil uji regresinya adalah pengetahuan keselamatan secara signifikan menengahi hubungan antara OHSMF dan kecelakaan serta cedera di tempat kerja. Pengetahuan keselamatan kerja tercatat lemah namun didapatkan korelasi positif signifikan 0,341 dengan OHSMF dan menghasilkan korelasi negatif signifikan yakni 0,380 dan -0,340 dengan kecelakaan kerja dan cedera terkait pekerjaan. ${ }^{6}$

Berdasarkan informasi yang telah dikumpulkan dan dijabarkan diatas dapat diketahui bahwa K3 merupakan salah satu upaya penting dalam pencegahan kecelakaan kerja dan penyakit akibat kerja. Apabila K3 ini dikelola dengan baik, memadai, dan terjamin bagi semua pekerja maka akan terbentuk komitmen kerja yang tinggi. Kemudian, bila pekerja memiliki komitmen kerja yang tinggi maka produktivitas pekerja akan meningkat diikuti dengan proses kerja yang efektif dan efisien. Sebagai upaya penerapan K3 yang baik perlu dilakukan peningkatan pengetahuan K3 pekerja melalui safety talk, pendidikan K3, dan pelatihan K3. Upaya ini penting diterapkan karena pengetahuan K3 yang tinggi pada pekerja akan menimbulkan 
perubahan sikap positif dalam keamanan kerja. Sikap positif ini bisa dipertahankan dengan adanya regulasi, baik dalam proses produksi, lingkungan kerja, maupun pekerja.

Selain peningkatan pengetahuan K3 pada pekerja, penerapan K3 juga perlu dukungan supervisor atau manajemen perusahaan yang konsisten dalam melakukan manajemen risiko dan dapat menyelesaikan masalah terkait K3 secara komprehensif serta mampu berkolaborasi dengan pihak lain demi peningkatan kualitas K3 di tempat kerja. Beberapa penelitian terkait judul karya tulis ini memiliki persamaan hasil yakni tingkat pengetahuan pekerja terkait $\mathrm{K} 3$ terbukti mempengaruhi kejadian kecelakaan kerja di sektor kesehatan, perikanan, industri, dan pertambangan. Informasi yang didapatkan masih terbatas keempat sektor tersebut sehingga perlu dilakukan penelitian lebih lanjut pada sektor lain misalnya seperti sektor perminyakan, pertanian, transportasi, pariwisata, dan lain sebagainya.

\section{Kesimpulan}

Kecelakaan kerja dapat dicegah dengan berbagai upaya seperti meningkatkan pengetahuan K3 pekerja; melakukan manajemen risiko melalui identifikasi, penilaian, dan pengendalian; serta menerapkan risk mapping. Bentuk peningkatan pengetahuan K3 pekerja berupa safety talk, pendidikan $\mathrm{K} 3$, dan pelatihan K3 secara rutin serta diperlukan penyusunan regulasi untuk mendukung terlaksananya $\mathrm{K} 3$. Tingkat pengetahuan K3 ini perlu ditanamkan kepada pekerja karena dari beberapa penelitian terbukti mempengaruhi kejadian kecelakaan kerja baik di sektor kesehatan, perikanan, industri, maupun pertambangan. Dimana semakin tinggi tingkat pengetahuan K3 pada pekerja di suatu tempat kerja maka akan semakin rendah kejadian kecelakaan kerjanya. Saran untuk karya tulis selanjutnya adalah: 1) Perlu dilakukan penelitian mengenai hal-hal yang mempengaruhi tingkat pengetahuan $\mathrm{K} 3$ para pekerja, 2) Perlu dilakukan penelitian dan pengkajian lebih dalam pada variabel-variabel lain yang dapat mempengaruhi kejadian kecelakaan kerja di tempat kerja selain variabel tingkat pengetahuan pekerja terkait K3 yang telah digunakan pada penelitian ini, dan 3) Perlu dilakukan penelitian terkait hubungan tingkat pengetahuan K3 terhadap kejadian kecelakaan kerja yang difokuskan pada sektor-sektor tertentu.

\section{Ucapan Terima Kasih}

Kami mengucapkan terima kasih yang sebesar-besarnya kepada Fakultas Kedokteran Universitas Muhammadiyah Malang atas dukungannya selama penulisan artikel ini.

\section{Referensi}

1. ILO. Investigation of Occupational Accidents and Diseases. Geneva: International Labour Office; 2015.

2. BPJS Ketenagakerjaan. Angka Kecelakaan Kerja Cenderung Meningkat, BPJS Ketenagakerjaan Bayar Santunan Rp1,2 Triliun [Internet]. 2019 Jan [cited 2019 Nov 21]. Available from: https://www.bpjsketenagakerjaan.go.id/berit a/23322/Angka-Kecelakaan-Kerja-Cender.

3. KOMINFO JATIM. Sebanyak 101 Pekerja di Jatim Meninggal Dunia Akibat Kecelakaan Kerja [Internet]. 2018 Jan [cited 2019 Nov 21]. Available from: http://kominfo.jatimprov.go.id/read/umum/s ebanyak-101-pekerja-di-jatim-meninggaldunia-akibat-kecelakaan-kerja.

4. Irzal. Dasar-Dasar Kesehatan dan Keselamatan Kerja. 1st ed. Jakarta: Kencana; 2016.

5. Untung H. Promosi Kesehatan di Tempat Kerja. Malang: Wineka Media; 2018.

6. Liu S, Nkrumah ENK, Akoto LS, Gyabeng E, Nkrumah E. The State of Occupational Health and Safety Management Frameworks (OHSMF) and Occupational Injuries and Accidents in the Ghanaian Oil and Gas Industry: Assessing the Mediating Role of Safety Knowledge. BioMed Research International. 2020;2(2020):1-14.

7. Dita M, Atmojo TB, Sari Y, Susilawati TN. 
The Correlation Between Knowledge About Occupational Accidents and Safe Work Behaviors Among Employees at the Production Division of PT X Indonesia. The 1st International Conference on Health, Technology and Life Sciences, KnE Life Sciences. 2019;2019:123-131.

8. Kamdhari E, Ersalita D. Penerapan Sistem Manajemen Keselamatan dan Kesehatan Kerja (SMK3) pada Proyek Female Apartment Adhigrya Pangestu. Jurnal Politeknologi. 2018;17(1):17-26.

9. Vasconcelos B, Junior BB. The Causes of Work Place Accident and Their Relation to Construction Equipment Design. Procedia Manufacturing. 2015;3(2015):4392-4399.

10. Lunner-Kolstrup C, Ssali TK. Awareness and Need for Knowledge of Health and Safety among Dairy Farmers Interviewed in Uganda. Frontiers in Public Health. 2016;4(137):1-10.

11. Amponsah-Tawiah K, Mensah J. Occupational Health and Safety and Organizational Commitment: Evidence from the Ghanaian Mining Industry. Safety and Health Work. 2016;7(2016):225-230.

12. Mohammadfam I, Kamalinia M, Momeni M, Golmohammadi R, Hamidi Y, Soltanian A. Evaluation of the Quality of Occupational Health and Safety Management Systems Based on Key Performance Indicators in Certified Organizations. Safety and Health Work. 2017;8(2):156-161.

13. Setyowati DL, Pratiwi D, Sultan M. Hubungan Pengetahuan, Sikap, Pelatihan, Pengawasan dengan Persepsi tentang Penerapan SMK3. Faletehan Health Journal. 2018;5(1):19-24.

14. Trevethan R. 2017. Deconstructing and Assessing Knowledge and Awareness in Public Health Research. Frontiers in Public Health. 2017;5(194):1-6.

15. Rinawati S, Widowati NN, Rosanti E. Pengaruh Tingkat Pengetahuan Terhadap Pelaksanaan Pemakaian Alat Pelindung Diri Sebagai Upaya Pencapaian Zero Accident di
PT. X. Journal of Industrial Hygiene and Occupational Health. 2016;1(1):53-67.

16. Syaputra EM. Hubungan Pengetahuan dan Motivasi K3 dengan Kecelakaan Kerja Karyawan Produksi PT. Borneo Melintang Buana Eksport. Jurnal Kesehatan Masyarakat Health. 2017;2(3):97-103.

17. Gumelar F, Ardyanto D. Hubungan Kepatuhan dan Pengetahuan Tentang APD dengan Safety Talk Di Unit Maintenance Perusahaan Semen. Journal of Public Health Research and Community Health Development. 2018;2(2):155-165.

18. Rumchev K, Gilbey S, Mead-Hunter R, Selvey L, Netto K, Mullins B. Agricultural Dust Exposures and Health and Safety Practices among Western Australian Wheatbelt Farmers during Harvest. International Journal of Environmental Research and Public Health. 2019;16(24):113.

19. Berumen-Flucker B, Rodriguez A, Cienega L, Douphrate DI, Porras DGRDE, Casanova V, Pompeii L. Evaluation of Safety Management and Leadership Training Using Mobile Technologies Among Logging Supervisors. J Agromedicine. 2019;24(2):197-204.

20. Susanto N, Budiawan W, Purwaningsih R, Sabrina DR. Implementasi Perbaikan Perilaku Kerja Aman Menggunakan Pendekatan Behaviour-Based Safety pada Industri Batik di Kota Semarang. Jurnal Ergonomi dan K3 ITB. 2019;4(1):16-23.

21. Oztas D, Kurt B, Koc A, Akbaba M, Iter H. Knowledge Level, Attitude, and Behaviors of Farmers in Çukurova Region regarding the Use of Pesticides. Hindawi BioMed Research International. 2018;2018:1-7.

22. Ismail S, Awan $S$, Naeem R, Siddiqui S, Afzal B, Jamil B, Khan UR. Occupational Exposure to HIV in A Developing Country: Assessing Knowledge and Attitude of Healthcare Professional Before and After an Awareness Symposium. BMC Research Notes. 2018;11(131):1-6. 


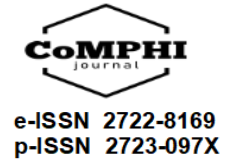

23. Teja MBS, Sutarja IN, Diputra GdA. Occupational Health and Safety Pengaruh Pengetahuan Keselamatan dan Kesehatan Kerja Terhadap Perilaku Pekerja Konstruksi pada Proyek Jalan Tol Nusa DuaNgurah Rai-Benoa. Jurnal Spektran. 2017;5(1):1-87.

24. Novianto AE, Sugiyarto, H Sri F. Analisis Pengaruh Kesehatan dan Keselamatan Kerja (K3) Terhadap Kinerja Pekerja Konstruksi Pada Proyek Pembangunan Fly Over Palur. Jurnal Matriks Teknik Sipil. 2016;4(4):10941102.

25. Altunkaynak B. A Statistical Study of Occupational Accidents in The Manufacturing Industry in Turkey. International Journal of Industrial Ergonomics. 2018;66(2018):101-109.

26. Rudyarti E. Hubungan Pengetahuan Keselamatan dan Kesehatan Kerja dan Sikap Penggunaan Alat Pelindung Diri dengan Kejadian Kecelakaan Kerja pada Pengrajin Pisau Batik Di PT. X. Journal of Industrial Hygiene and Occupational Health. 2017;2(1):31-43.

27. Aluko OO, Adebayo AE, Adebisi TF, Ewegbemi MK, Abidoye AT, Popoola BF. Knowledge, Attitudes and Perceptions of Occupational Hazards and Safety Practices in Nigerian Healthcare Workers. BMC Research Health. 2016;9(71):1-14.

28. Rosalita NA, Ratmawati D, Agustina TS. Mediasi Safety Knowledge dan Safety Motivation pada Pengaruh Safety Management Practices Terhadap Safety Performance Karyawan Bagian Produksi PT. Petrokimia Gresik. Jurnal Manajemen Teori dan Terapan. 2015;8(3):201-205.

29. Pertiwi, Yudha N, Santosa B. Hazard Identification, Risk Assesment, and Risk Control serta Penerapan Risk Mapping pada Rumah Sakit Hewan Prof. Soeparwi Universitas Gadjah Mada. BKM Journal of Community Medicine and Public Health. 2019;35(2):55-64.

30. Yanar B, Lay M, Smith PM. The Interplay Between Supervisor Safety Support and 